DMYTRO BILYI,

\title{
UKRAINIZATION IN KUBAN IN THE 1920s AND 1930s: LEGITIMATION AND DELEGITIMATION THROUGH THE PRISM OF HISTORICAL MEMORY
}

\begin{abstract}
The processes of revival of Ukrainian culture and education which unfolded among the Ukrainian population of the North Caucasus (mainly - of Kuban) in the 1920s and 1930s have been examined in the article. The scientific novelty and relevance of the study are due to the fact that, for the first time, the author has attempted to reveal the preconditions, circumstances, course and consequences of national and cultural development of the Ukrainian population in Kuban in 19201933 on the basis of available sources and analysis of existing literature. The reasons for this development and the structures that provided it both at the level of spontaneous initiative of local Ukrainians and due to the influence of certain official events and institutions have been highlighted in the article. Particular attention is paid to the dynamics of providing for the needs of Ukrainians in Kuban both in education in their native language and other national and cultural needs. The processes and mechanisms of transition of schools of all levels in Kuban to the Ukrainian language, creation and activity of Ukrainian-language publishing houses, theatrical, literary and musical associations have been considered. In the early 1930s, these rather large processes began to be held back by the central government. They were completely stopped at the beginning of 1933, which was accompanied by the Holodomor, the physical elimination of many Ukrainians in Kuban and assimilation de-Ukrainization processes. The reasons for this anti-Ukrainian policy and its consequences have also been considered in this article.
\end{abstract}

Key word: Kuban; North Caucasus; Ukrainization; national development; education.

\section{Introduction}

The chronological framework of our study covers the periods from 1921 to 1932 . The choice of this time in the history of the study of the Ukrainian community in Kuban was caused by a number of circumstances. In 1921, the civil war ended, the Ukrainians in Kuban entered a new period of their existence under the conditions of fundamental restructuring of all the usual social, political and economic living conditions. However, there still were strong national and cultural movements in Kuban, caused by the extremely high uplift connected with the attempt at political and national state-building under the conditions of the Kuban People's Republic (1918-1920). The rapid growth of national self-consciousness of Ukrainians in Kuban did not stop after the victory of the Soviet power. On the contrary, since the mid-1920s, the general nationbuilding process in the USSR had begun to create favorable conditions for the national and cultural development of Ukrainians in Kuban. During this period, state and administrative mechanisms had been developed, which greatly enabled Kuban Ukrainians to receive education in their native language, to have their own Ukrainian publishing house, newspaper, and to strengthen connections with Ukraine and other Ukrainian communities in the USSR. But, at the same time, trends towards stopping the process of korenizatsiya (indigenization) - the Ukrainization in Kuban - began to appear among the party and state apparatus in these years. These trends led to the destruction of almost all the national and cultural development of Ukrainians in Kuban and even a rapid change in ethnic patterns of the population. These de-Ukrai-

ISSN 1728-9343 (Print)

ISSN 2411-3093 (Online) nization processes took place in 1932-1933 and were closely related to collectivization, the Holodomor, and the struggle against Ukrainian "national deviationism". After that, at the official level, the "Ukrainian national question" had not practically been raised and the indigenous Ukrainian population, in fact, became officially considered Russian. Thus, the completed stage in the national and cultural development of the Ukrainian population of $\mathrm{Ku}$ ban under Soviet rule in 1921-1932 can be traced. This period has a clear beginning and end, the stage of highest development. We can trace certain circumstances and factors that acted at that time and determined the specific features of the national and cultural development of the Ukrainians in Kuban.

The topic of national and cultural development of Kuban Ukrainians in 1921-1932 was hardly studied in Soviet historiography. Despite the huge number of collective works and monographs devoted to various aspects of nation-building during this period, only a few of them are related to this topic, in addition, rather superficially, in line with the official ideology. Unfortunately, this trend continues in contemporary Russian historical research, and the topic of national and cultural development of Ukrainians in Kuban still remains largely unaddressed by Ukrainian researchers. Therefore, our article is based on the materials found by the author in the archives in Ukraine and Russia, and on their basis we will try to highlight all the complexities of both processes of Ukrainization in Kuban and the destruction of their achievements by the totalitarian system.

SKHID No. 4 (168) July-August 2020 


\section{Research methods}

To actualize the scientific problem, which, as mentioned above, did not receive proper coverage in historiography, the theoretical analysis of archival sources, periodicals of the time, special studies and memoirs has been conducted and, for the first time, the preconditions, circumstances, course and consequences of national and cultural development of the Ukrainian population in Kuban in 1920-1933 have been defined; in addition, new archival information and statistical information, which is an important empirical material for studying the processes of revival of Ukrainian culture and education in the Kuban in this period, has been introduced into scientific use. The combination of both factual materials and analytical approach, interpretation of commemorative practices (historical memory), verification of available sources based on content analysis, combination of historical-chronological and historical-genetic approaches play a particularly important role in comprehending and covering the targets.

Results and discussion

The national and cultural development of Ukrainians in Kuban in 1921-1932 was conditioned by and depended on many factors that arose in the historical period between the establishment of Soviet power in Kuban and the final establishment of Stalin's repressive dictatorship, which had fatal consequences for the Ukrainian population in Kuban (Bilyi, 2010). The compact resettlement of the Black Sea Cossack Host to Kuban in the 18th century formed the dominant Ukrainian community with established traditions, preservation of historical memory, economic and social system. New settlers from Ukraine had constantly swelled the Ukrainian population in Kuban, integrated into the social structure created by the Black Sea Cossacks, which ensured the secure preservation of their national identity, and at the same time these settlers maintained a sense of close contact with Ukraine among local Ukrainians. The life of the Ukrainians in Kuban, who were mostly part of the Cossack social state, under the conditions of constant war with the mountaineers led to a high level of mutual assistance and solidarity. The unchanging patriarchal structure of the Ukrainian peasant community preserved in Kuban was to preserve Ukrainian folk culture consistent with it.

By the end of the 19th century, Kuban had already established itself as a highly-developed agricultural region, which gave Kuban Ukrainians a sense of the originality of their land and the need to fight for the deepening of its autonomy.

The population of Kuban and its local national structure can be evidenced by the data of the All-Russian census conducted in 1897. According to it, the population of the Kuban region at that time was $1,911,133$ people (Makedonov, 1907: 546). According to this census, the Ukrainian-speaking population of the Kuban region was $49.7 \%$, or 949,833 people, and Russian-speaking was $39 \%$, or 745,341 people (Makedonov, 1907: 570).

Protecting their national culture from the negative influence of the imperial Russification policy, the Ukrainians of Kuban united around the ideas of the Ukrainian national liberation movement.

During the 19th and early 20th century, the influence of national and cultural development that took place in Ukraine was spreading in Kuban.

During the civil war in Kuban, the majority of the Ukrainian local population had shown a high level of national consciousness and understanding of their own national interests. The intense struggle for national selfidentification in these years manifested itself in the estab- lishment of the independent Kuban People's Republic, where Ukrainian political leaders dominated, the desire to unite with Ukraine and the Ukrainization of education.

By 1921, the national and cultural development among Ukrainians in Kuban had reached a sufficiently high level, and the majority of the Ukrainian population took part in it.

Without their own national-state structures and even national-territorial autonomy, Kuban Ukrainians saw the only opportunity to support national and cultural development in protecting the functioning of their language in educational institutions.

According to the All-Union census of 1926, the number of Ukrainians in Kuban was 1,141,000 people, or $66 \%$ of the region's total population ${ }^{1}$.

In fact, until 1926, the national and cultural development of Kuban Ukrainians was concentrated primarily in field of Ukrainization of local schools. In most cases, the Ukrainization of schools was initiated by stanitsa and khutor communities.

At the level of administrative institutions, the Ukrainization was supported only by certain representatives of the local Ukrainian intelligentsia - inspectors of district and regional departments of public education.

Until 1925, the state structures of the RSFSR and the USSR did not deal specifically with the issues of national and cultural development of Ukrainians in Kuban. But, during these years, there was an intensified Ukrainization in Ukraine, one of the directions of which was to ensure the national and cultural needs of Ukrainians living outside the USSR.

Gradually, state and party bodies of the RSFSR and the USSR began to increasingly support the Ukrainization in Kuban under the influence of the decisions of the Comintern and the pressure of the leadership of the USSR, as well as under the growing demands of the Ukrainian population in Kuban.

Since 1927, the processes of Ukrainization in Kuban began to deepen significantly. National and cultural development went beyond public education, the Soviet and party apparatus, newspapers, publishing houses began to be Ukrainized, and the activities of Ukrainian local writers and musicians were extended. At this time, it can be seen how the deep processes of national self-identification that had long developed among the Ukrainian population in Kuban found widespread support from government agencies. All segments of the Ukrainian population in Kuban were involved in national and cultural development. Gradually, the Ukrainians in Kuban were able to have their own educational institutions from kindergartens to universities, their own newspapers, Ukrainian literature. Connections with Ukraine were rapidly strengthened, and the work of local Ukrainian artists developed.

Undoubtedly, this process had its disadvantages: distortion and inhibition by the bureaucratic apparatus, chauvinistic circles, attempts to keep national and cultural development within relatively narrow formal limitations.

However, despite this, it played a huge positive role in the national and cultural construction in Kuban, gave local Ukrainians the opportunity to express widely their creative potential, contributed to the establishment of inter-ethnic relations and civil peace in the country.

In 1932, the North-Caucasus Pedagogical Institute (Krasnodar) was renamed the North-Caucasus Ukrainian Pedagogical Institute named after Skrypnyk, in the same

${ }^{1}$ Central State Archive of Public Associations of Ukraine (Центральний Державний Архів громадських об'єднань України). Fund I. D. 20. File 2894. Sh. 78-82. 
year, 164 teachers for Ukrainians in the North Caucasus, Siberia, Kazakhstan, the Far Eastern Republic had already graduated from it. In general, it was planned to increase the number of Ukrainian teachers to 415 per year by $1937^{2}$.

Unfortunately, we do not know how the dynamics of the number of Ukrainian schools in Caucasus and Kuban increased in 1930-1932, but the data show that in 1932 there were already up to 746 schools in Kuban (Conquest, 1993: 310).

There is evidence that at the end of 1932, when deUkrainization began in the North Caucasus, 1,609 primary schools with 221,463 students and 5,581 teachers and 259 middle schools with 42,148 students and 1,552 teachers, 12 pedagogical technical schools and shortterm pedagogical courses operated in Ukrainian, a network of mass political educational institutions also operated there. In other districts of Kuban, which did not become part of the Kuban Okrug after division into districts in 1925, Ukrainization processes were not identified by such intensity.

Gradually, during this period, Ukrainian book publishing began to develop in the North Caucasus. While from 1920 to 1927, only 3 Ukrainian-language books were published in the North Caucasus (Sulyatytskyy, 1929. 16), the situation began to change fundamentally over time, as we can see below.

Despite the fact that, at the First National Ukrainian Teachers' Congress in 1925, the question of publishing a Kuban local history textbook for Ukrainian schools by the school year (1926-1927) beginning was raised, it had never been published. In 1927, the North Caucasian publishing house "Sevkavvyd" published the Ukrainian primer "Nove Selo" ("New Village"). In 1928, Ukrainian textbooks "Nove Selo", "Novym Shlyahom" ("By New Way"), primer "Zhivi Zvuky" ("Living Sounds") were published. In 1929, a Ukrainian textbook for the 3rd year of study "Novym Shlyahom", a textbook on mathematics for the 2nd year of study, lectures for self-education "Ukrainian language" and "Arithmetic Course" (Zaremba, 1993: 100) were published. Mass production of Ukrainian literature began in 1931, when the publishing houses of the North Caucasus published 149 Ukrainian books and brochures, works by local Ukrainian-language writers with a total circulation of 958,000 copies. According to the plan of 1932, it was planned to publish 600 titles with a circulation of 4,880,000 copies (Krykulenko, 1990). The Ukrainianlanguage press played an important role in Ukrainization in the North Caucasus. In 1925, a weekly supplement to the North Caucasus Soviet organ "Krasnoe Znamya" ("Red Banner") (Rostov-on-Don) "Radyanskyi Stanychnyk" ("Soviet Villager") with a total circulation of 1,900 copies was translated into Ukrainian. The Ukrainian publishing houses "Chervonyi Prapor" ("Red Flag") and "Radyanskyi Stanychnyk" (Zastavnyy, 1992: 71) began to operate very quickly.

The processes of the elimination of Ukrainization and the forcible Russification of Ukrainians in Kuban was directly related to collectivization and the creation of an artificial famine in the region, which in fact led to the genocide of Ukrainians.

Collectivization was most radical in Ukraine and the North Caucasus, where the peasantry was the richest.

In Kuban, collectivization was further complicated by the presence of a consolidated Cossack population ready to resist the innovations of the Soviet government with weapons. In order to break the resistance of the Ukrai-

\footnotetext{
${ }^{2}$ Красное знамя (м. Краснодар) - №118 (1930р.)
}

ISSN 1728-9343 (Print)

ISSN 2411-3093 (Online) nian peasantry in Kuban, in July 1932, the authorities resorted to a significant destruction of grain procurement quotas, which led to a famine, which reached enormous proportions, in these areas ${ }^{3}$.

By exterminating the peasantry in Kuban, the Soviet leadership at the same time was aimed at stopping the development of trends directed at increasing the efforts of Ukrainians to determine their own political future. No wonder the blow aimed at significant elements of the national statehood of the USSR did not avoid the Ukrainian population in Kuban. Simultaneously with the pressure on the Ukrainian peasantry as the main basis of human existence of the Ukrainian nation, the destruction of the Ukrainian intelligentsia and Ukrainian cultural institutions began. And while the status of Ukraine's existence as a state allowed to preserve the heritage of the previous national and cultural revival to some extent, the Ukrainians in Kuban, not even protected by national autonomy within the RSFSR, were subjected to the extraordinary brutal destruction of their national and cultural heritage.

Mass arrests of Ukrainian intelligentsia in the Kuban began in 1929-1931 in connection with the cases of "The Union of Kuban and Ukraine" and "The Union for the Liberation of Ukraine". But as thousands of dispossessed Ukrainian peasants were deported from Kuban, administrative authorities were increasing the pace of Ukrainization of the region. In June 1932, at a meeting of the North Caucasus Regional Executive Committee, orders were issued warning of the personal responsibility of the heads of district executive committees for delaying the Ukrainization ${ }^{4}$. But, at the end of 1932, a resolution was issued in Moscow, which not only canceled all the achievements of Ukrainization, but also had slowed down any manifestations of national and cultural development of Ukrainians in Kuban for many years and decades. This was the resolution by Central Committee of the Communist Party of the Soviet Union and the Council of People's Commissars of the Soviet Union of December 14, 1932 on grain procurement in the North Caucasus and Western regions, signed by chairman of the Council of People's Commissars of the Soviet Union V. Molotov and General Secretary of the Central Committee of the CPSU J. Stalin.

The resolution strongly criticized the rapid pace of Ukrainization in Ukraine and prohibited its implementation in the North Caucasus. Thus, it was ordered to transfer immediately the paperwork of the Soviet and cooperative bodies of Ukrainian districts, as well as all journals published in Ukrainian in the North Caucasus into Russian "as more understandable to Kubanians, as well as to prepare and transfer teaching into Russian by the fall". The Central Committee and the Council of People's Commissars undertook to check and "improve the composition of administration in Ukrainianized schools".

At the same time, it was ordered: "to expel urgently to the northern regions of the USSR from the Poltava stanitsa (North Caucasus) ... all inhabitants except those truly loyal to the Soviet government..." (Holod 1932 - 1933 rokiv..., 1990: 91-294).

This resolution reduced to nothing any ensuring national and cultural rights of Ukrainians in Kuban, in fact,

\footnotetext{
${ }^{3}$ Про голод на Україні і Кубані див.: Holod 1932 - 1933 rokiv na Ukrayini: ochyma istorykiv i movoyu dokumentiv, 1990; Kolektyvizatsiya i holod v Ukrayini 1929 - 1933, 1992; Byuleteni dopomohy holoduyuchym Ukrayiny i Kubani, 193334; Conquest, 1993; Levchenko, 1989.

4 State Archives of the Krasnodar Territory (Державний Архів Краснодарського Краю). Fund. p-580. D. 1. File 394. S. 17.
}

SKHID No. 4 (168) July-August 2020 
denied the right of Ukrainian Kubanians to consider themselves Ukrainians officially and at the same time initiated the mass deportation of the Ukrainian population in Kuban, starting with the most nationally and culturally developed Ukrainian stanitsa of Kuban Poltava, in which the percentage of Ukrainians wase more than $80 \%$ of the population (Conquest, 1993: 309).

The de-Ukrainization of Kuban was conducted quickly and expeditiously by the local authorities, which implemented the resolution peremptorily. On December 29, 1932, at a meeting of the Presidium of the North Caucasus Regional Executive Committee, a resolution on Ukrainization was adopted. In it, under the pretext of the fact that "the Ukrainization of a number of districts and stanitsas in the North Caucasus did not proceed from the cultural interests of the population and served as a legal form for the class enemy to resist Soviet measures and form counterrevolutionary organizations under this guise", it was strongly proposed to stop the Ukrainization process, to transfer office work in Soviet organizations and stanitsas and districts into Russian by January 1, 1933, to transfer Ukrainianized newspapers, as well as leaflets, brochures, multi-circulation, wall posters and other literature in Ukrainian into Russian in 3 days, to transfer the teaching of all working short-term courses (Soviet, pedagogical, collective farm, etc.) into Russian, to transfer teaching in all schools into Russian by the fall of 1933, to stop broadcasting in Ukrainian ${ }^{5}$.

On December 22, 1932, an editorial appeared in the press organ of the North Caucasus Regional Committee of the CPSU, the regional executive committee and the regional council, the newspaper "Molot" ("Hammer"), which justified that "the Poltava stanitsa, in the past a citadel of Russia, the center of the national-bourgeois movement, has become the center of particularly stubborn anti-Soviet sabotage". Stopping of Ukrainization was explained by the fact that it revived the ideology of bourgeois nationalism in Kuban, was conducted and taught in Ukrainian schools by bourgeois nationalists, White Guards, Petliurists, Samostiynyky, kulaks, etc. In this article, Ukrainization was seen as a counter-revolutionary policy pursued by the enemies of the people to gather in the Kuban "the best cadres of interventionists and counter-revolutionaries." Ukrainian books, newspapers and journals published in the North Caucasus were accused of cultivating nationalist ideas of "Kuban independence", of perverting Lenin's party policy. All these publications were offered to be immediately translated into Russian "as more understandable to Kubanians". The eviction of the inhabitants of the Poltava stanitsa and the prohibition of Ukrainization were seen as a solution to one problem the defeat of kulak sabotage and the ideology of Kuban bourgeois nationalism and its specific carriers in Kuban.

The editorial set a specific task to destroy all manifestations of Ukrainian national consciousness in Kuban, marking it as an ideology of bourgeois nationalism. This meant not only the closure of Ukrainian schools and newspapers, but also the physical destruction of those who carried this consciousness. On February 13, 1933, the Board of the People's Commissariat for Education of the RSFSR issued the "Resolution on the implementation of the decision of the directive bodies in connection with the Ukrainization of public education institutions", which developed measures for the transfer of "Ukrainia-

\footnotetext{
${ }^{5}$ State Archives of the Krasnodar Territory (Державний Архів Краснодарського Краю). Fund P-1594. D 1. File 50. S. 614.
}

nized" educational institutions from Ukrainian language to Russian.

The de-Ukrainization was conducted by a special commission, to which the responsible heads of many departments of the RSFSR and the USSR reported on the work done. Thus, on July 9, 1933, the People's Commissars for Education of the RSFSR A. Bubnov in his report to the special commission confirmed the practical implementation of the Resolution of the RSFSR NKO that all Ukrainian schools in the RSFSR would be transferred into Russian until the fall of $1933^{6}$.

De-Ukrainization was conducted very quickly and firmly. One of the newly arrived teachers of the Ukrainian pedagogical technical school in the Uman stanitsa wrote that, on February 20,1933, he was called to the NKVD, where he was ordered to collect all Ukrainian textbooks and bring them there, and that the technical school would be transferred into Russian. On the second day he received Russian books, and in the technical school teaching in Russian began (Polezhayev, 1988).

The consequences of the de-Ukrainization work undertaken in the North Caucasus and Kuban are evidenced in particular by a report sent to the People's Commissariat for Education of the RSFSR on April 22, 1933. It stated that by the spring of 1933, in all schools in the North Caucasus it had been exclusion of teaching in Ukrainian and exclusion of Ukrainian language as a special subject, and Russian was introduced instead, in all Ukrainian schools where a proper number of textbooks existed, teaching had already been fully transferred into Russian, and others would be transferred by the fall of $1933^{7}$. By March 1, 1933, all 12 Ukrainian pedagogical colleges had been transferred into Russian. During the transfer of these technical schools into Russian, the pedagogical staff was removed, and, as a result, it was completely renewed in Uman and Poltava technical schools, and in other technical schools it was largely renewed. The work of all short-term courses, as was the work of all political and educational institutions was completely transferred into Russian in December 1932.

Russian language courses were urgently opened for teachers of former Ukrainian schools, and a short-term optional Russian language course was opened at the correspondence department of the Krasnodar Pedagogical Institute ${ }^{8}$. Destroying the results of Ukrainization, the Stalinist leadership left the population of Kuban without historical memory, national and cultural basis, which made it easier for the state to stratify the population, to break its resistance.

\section{Conclusions}

Until 1925, the state structures of the RSFSR and the USSR did not deal specifically with the issues of national and cultural development of Ukrainians in Kuban. But during these years in Ukraine there was an intensified Ukrainization, one of the directions of which was to provide for the national and cultural needs of Ukrainians living outside the USSR.

Gradually, under the influence of the decisions of the Comintern and the pressure of the USSR leadership, as well as under the growing demands of the Ukrainian population in Kuban, state and party bodies of the RSFSR and the USSR began to increasingly support the Ukrainization in Kuban.

\footnotetext{
${ }^{6}$ Ibid... S. 11.

7 Державний Архів Ростовської Області (State Archives of the Rostov Region). Fund 64. File 77. S. 13.

${ }^{8}$ Ibid... S. 14 - 15.
} 
Since 1927, the processes of Ukrainization in Kuban began to deepen significantly. National and cultural development went beyond public education, the Soviet and party apparatus, newspapers, publishing houses began to be Ukrainized, and the activities of Ukrainian local writers and musicians were extended. At this time, it can be seen how the deep processes of national self-identification that had long developed among the Ukrainian population in Kuban found widespread support from government agencies. All segments of the Ukrainian population in Kuban were involved in national and cultural development. Gradually, the Ukrainians in Kuban were able to have their own educational institutions from kindergartens to universities, their own newspapers, Ukrainian literature. Connections with Ukraine were rapidly strengthened, and the work of local Ukrainian artists developed.

Undoubtedly, this process had its disadvantages: distortion and inhibition by the bureaucratic apparatus, chauvinistic circles, attempts to keep national and cultural development within relatively narrow formal limitations.

However, despite this, it played a huge positive role in the national and cultural construction in Kuban, gave local Ukrainians the opportunity to express widely their creative potential, contributed to the establishment of inter-ethnic relations and civil peace in the country.

The general changes connected with the strengthening of the trends of establishing a brutal totalitarian dictatorship led by Stalin stopped the national and cultural development of the Ukrainians in Kuban and destroyed its consequences. This was caused by the victory of forces set up to deprive the socialist republics of their independence and to strengthen chauvinistic great-power sentiments in the leadership of the USSR.

The offensive against the achievements of the previous national and cultural development began simultaneously with the policy of destroying the foundations of socio-economic and social life of the local Ukrainian population. A policy of social collectivization was implemented, accompanied by mass deportations and repres- sions of Kuban Ukrainians. In fact, a quite conscious policy was implemented aimed at changing the ethnodemographic situation in Kuban. As a result, the local Ukrainian population was partially annihilated through mass deportations, repression and Holodomor, and the rest were recorded as Russian in official documents. Thus, the national and cultural development of the Ukrainian population in Kuban was artificially stopped, and its consequences were carefully destroyed.

\section{REFERENCES}

Bilyi, D. (2010). Holodomor ta polityka deukrayinizatsiyi na Kubani $\vee 1929-1933$ rokakh. Henotsyd Ukrayiny $\vee$ XX stolitti: Materialy Vseukrayinskoyi naukovo-praktychnoyi konferentsiyi. Lviv: 364 - 376 (In Ukranian).

Makedonov, L. V. (1907). Naseleniye Kubanskoy oblasti po dannym vtorykh ekzemplyarov listov perepisi 1897. Katerinodar (In Russian).

Conquest, R. (1993). Zhnyva skorboty. Radyanska kolektyvizatsiya i holodomor. Kyiv: Vyd-vo "Lybid"', 280 p. (In Ukrainian)

Sulyatytskyy, P. (1929). Ukrayinizatsiya na Kubani. Tryzub (Paryzh). 42: 16 (In Ukrainian)

Zaremba, S. (1993). Z natsionalno-kulturnoho zhyttya ukrayintsiv na Kubani. Kyyivska starovyna, 1 (In Ukrainian).

Krykulenko, V. (1990, May 10). Visti do Atlantydy. Literaturna Ukrayina (In Ukrainian).

Zastavnyy, F. D. (1992). Skhidna ukrayinska diaspora. Lviv: Svit (In Ukrainian).

Byuleteni dopomohy holoduyuchym Ukrayiny i Kubani (19331934). Bruxel (In Ukrainian).

Kolektyvizatsiya i holod v Ukrayini 1929 - 1933. (1992). Zbirnyk dokumentiv i materialiv. Kyiv: Naukova dumka, 736 p. (In Ukrainian).

Levchenko, V. (1989). Chernyye doski. Kuban. 7: 17 - 62 (In Russian).

Holod 1932 - 1933 rokiv na Ukrayini: ochyma istorykiv i movoyu dokumentiv (1990). Kyiv: Vydavnytstvo politychnoyi literatury Ukrayiny, pp. 291 - 294 (In Ukrainian).

Polezhayev, I. (1988, December 17). Zhivem trevozhno, no vperedi mirovaya revolyutsiya... Dnevnik iz 1933 goda. Sovetskaya Kuban. (In Russian).

\title{
Дмитро Білий,
}

Національний музей Голодомору-геноциду, Інститут дослідження Голодомору (м. Київ, Україна)

e-mail: bilyjdm@gmail.com,ORCID 0000-0003-2941-3055

\section{УКРАЇНІЗАЦІЯ НО КУБАНІ В 20-30-Х рр. ХХ ст: ЛЕГІТИМАЦІЯ ТА ДЕЛЕГІТИМАЦІЯ КРІЗЬ ОПТИКУ ІСТОРИЧНОЇ ПАМ'ЯТІ}

\begin{abstract}
У статті розглядаються процеси відродження української культури та освіти, які розгорнулися серед українського населення Північного Кавказу (переважно - Кубані) в 20-30-х pp. XX ст. Наукова новизна й актуальність дослідження зумовлюються тим, що автор робить спробу вперше на ґрунті доступних джерел та аналізу існуючої літератури розкрити передумови, обставини, перебіг i наслідки національнокультурного розвитку українського населення Кубані у 1920 - 1933 рр. У статті висвітлюються підстави цього розвитку та структури, які його забезпечували, як на рівні стихійної ініціативи місцевих українців, так і завдяки впливу певних офіційних заходів та інституцій. Окрема увага приділена динаміці забезпечення потреби українців Кубані як у освіті рідною мовою, так і інших національно - культурних потреб. Розглянуті процеси та механізми переходу шкіл всіх рівнів Кубані на українську мову, створення та діяльність україномовних видавництв, театральних, літературних та музичних об'єднань. На початку 1930-х років ці доволі масштабні процеси почали гальмуватися центральною владою та були повністю припинені на початок 1933 року, що супроводжувалося Голодомором - фізичним винищенням значної частини українців Кубані, та асиміляційними процесами деукраїнізації. Причини цієї антиукраїнської політики та її наслідки також розглядаються в цій статті.
\end{abstract}

Ключові слова: Кубань; Північний Кавказ; українізація; національний розвиток; освіта.

() Dmytro Bilyi

Надійшла до редакції: 01.07.2020

Прийнята до друку: 17.07.2020 